Adzra Afifah Mahmuda ${ }^{1}$ Maylinda Dwi Astuti ${ }^{2}$ Akmal Hisyam Mikdadi ${ }^{3}$ Achmad Ryan Ma'sum Saputra ${ }^{4}$ Darmadi $^{5}$

\section{ANALISIS KESULITAN DALAM PEMBELAJARAN MATEMATIKA MENGENAI MATERI BILANGAN BULAT DI KALANGAN SD PADA MASA PANDEMI}

\begin{abstract}
Abstrak
Filsafat ilmu dan Pendidikan memiliki peran yang besar dalam membentuk karakteristik media pembelajaran matematika. Dalam filsafat ini terdapat beberapa aspek dan dimensi yang menjadi landasan pembuatan media pembelajaran matematika yaitu aspek ide dan fakta, serta dimensi abstrak dan konkret baik secara teoritis maupun praktis. Dalam pembelajaran matematika sedikit banyaknya siswa yang masih kesulitan dalam belajar berhitung dan kekeliruan dalam menyelesaikan soal cerita, apalagi dimasa pandemi COVID-19. Maka dampak pandemi COVID-19 ini siswa menjadi kesulitan menerima Pendidikan karakter secara langsung dari guru-gurunya di sekolah. Kesulitan yang sering dialami oleh siswa yaitu kebingungan saat menentukan operasi hitung yang akan dipakai dan kesulitan saat mengerjakan soal cerita karena kurang mampu memahami maksud soal. Maka tujuan penelitian ini adalah menganalisis kesulitan siswa SD kelas IV dalam menyelesaikan soal operasi bilangan bulat dan solusi pemecahannya. Subjek penelitian ini adalah siswa kelas IV semester genap Sekolah Dasar Negeri 01 Kartoharjo Kota Madiun Jawa Timur. Teknik pengumpulan data yang digunakan adalah tes tertulis dan wawancara. Bedasarkan hasil penelitian disimpulkan bahwa kesulitan siswa dalam pembelajaran Operasi Bilangan Bulat, siswa masih belum mampu mengerjakan dengan baik, masih kuang teliti dalam mengerjakan, dan masih terkesan sangat buru-buru. Untuk mengatasi permasalahan tersebut, alternatif yang diberikan pada saat penelitian adalah memberikan bimbingan untuk memaknai isi dari soal yang diberikan, setelah siswa dapat memaknai isi dari soal kemudian siswa diminta untuk menyelesaikan soal tersebut.
\end{abstract}

Kata Kunci: Kesulitan Pembelajaran Matematika; Filsafat; Pandemi

\begin{abstract}
Philosophy of science and education has a big role in shaping the characteristics of mathematics learning media. In this philosophy there are several aspects and dimensions that form the basis for making mathematics learning media, namely aspects of ideas and facts, as well as abstract and concrete dimensions both theoretically and practically. In learning mathematics, more or less students still have difficulty in learning to count and make mistakes in solving story problems, especially during the COVID-19 pandemic. So the impact of the COVID-19 pandemic is that students find it difficult to receive character education directly from their teachers at school. Difficulties that are often experienced by students are confusion when determining the arithmetic operation to be used and difficulties when working on story

1,2,3,4,5) Prodi Pendidikan Matematika, FKIP, Universitas PGRI Madiun

Alamat e-mail: adzraafifahm@gmail.com¹, maylindadwi120@gmail.com², akmalhisam19@gmail.com³, saputraryan971@gmail.com ${ }^{4}$, darmadi.matedu@uipma.ac.id ${ }^{5}$
\end{abstract}


questions because they are not able to understand the meaning of the questions. So the purpose of this study was to analyze the difficulties of fourth grade elementary school students in solving integer operations problems and their solutions. The subjects of this study were fourth semester students of the State Elementary School 01 Kartoharjo, Madiun City, East Java. Data collection techniques used are written tests and interviews. Based on the results of the study, it was concluded that the difficulty of students in learning Integer Operations, students were still not able to do well, were still not thorough in working, and still seemed very rushed. To overcome these problems, the alternative given at the time of research is to provide guidance to interpret the contents of the questions given, after students can interpret the contents of the questions then students are asked to solve the questions.

Keywords: Math Learning Difficulties; Philosophy; Pandemic

\section{PENDAHULUAN}

Filsafat merupakan ilmu yang mempelajari semua yang ada di dunia ini. Filsafat mempunyai cakupan yang sangat luas, sehingga banyak sekali yang dapat kita pelajari di dalam filsafat. Ketika kita melakukan aktifitas sehari-hari, kita tak luput dari belajar tentang filsafat. Menurut Depag (2001) filsafat dapat diartikan sebagai ilmu yang mempelajari aturan-aturan atau norma dalam kehidupan. Belajar filsafat adalah belajar hidup, memahami bagaimana hidup kita berguna bagi diri kita sendiri dan orang lain. Belajar filsafat adalah memahami apa yang ada dan apa yang mungkin ada, artinya dalam hal ini menggunakan filsafat untuk belajar matematika adalah belajar logika.

Demikian pula peran filsafat ilmu dalam proses pembelajaran matematika merupakan landasannya. Kita tahu bahwa filsafat merupakan landasan dari berbagai ilmu lain, karena ketika mempelajari matematika, peran filsafat ilmu tidak dapat dipisahkan, terutama ketika menghubungkan berbagai masalah matematika, mereka menjadi rangkaian yang saling terkait, atau setidaknya mencari landasannya. Hubungan antara isu-isu ini. Demikian pula, kita juga mengetahui bahwa matematika dianggap sebagai ilmu yang berhubungan dengan berpikir, dan tujuan utamanya adalah untuk mencari kebenaran dalam proses pembelajaran filsafat dan matematika. Dalam mencari jawaban kebenaran, pembelajaran matematika tidak terlepas dari metode ilmiah (deduksi dan induksi) yang sejalan dengan fungsi filosofi sains, yaitu mengajukan serangkaian hal yang saling terkait untuk mencari jawabannya

Sejak adanya pandemi Covid-19, Indonesia harus membatasi aktivitas yang melibatkan banyak orang guna memutus penyebaran virus Covid-19. Sektor pendidikan salah satu yang terkena imbasnya. Kegiatan belajar mengajar di kelas terpaksa dialihkan ke sistem belajar daring (dalam jaringan). Pembelajaran daring di tengah pandemi Covid-19 memaksa guru untuk belajar memanfaatkan teknologi sebagai sarana penunjang pembelajaran. Di era digital seperti sekarang, belajar secara daring bukan hal yang baru sehingga meski pembelajaran tidak dilakukan tatap muka, KBM dapat tetap berjalan. Pada awalnya, siswa yang datang ke sekolah dengan mengenakan seragam sekolah biasanya tidak lagi melakukannya setiap pagi atau sore hari. Pembelajaran saat ini melibatkan teknologi berbasis internet. Selama pembelajaran daring, guru harus berpikir bagaimana cara menyampaikan materi pelajaran secara efektif meski tanpa bertatap muka langsung. Ini tentu menjadi suatu pekerjaan tersendiri, terlebih untuk pelajaran matematika yang identik dengan rumus dan menghitung. Dengan merebaknya pandemi virus corona, setiap aspek kehidupan telah berubah, termasuk bidang Pendidikan. Sejauh ini, jumlah orang yang terinfeksi virus corona telah mencapai 385.980, dan per 25 Oktober 2020, ada sebanyak 4.070 kasus baru. Korban tewas adalah 13.210. Hal ini menunjukkan kerentanan berbagai tempat umum, sehingga keputusan pemerintah masih melarang kegiatan belajar tatap muka di sekolah. Maka, siswa merasa sulit saat pembelajaran matematika Ketika tidak bertatap muka secara langsung.

Dalam pembelajaran Matematika umumnya dianggap pelajaran tersulit untuk anak-anak. Begitu juga dengan orang dewasa. Di sekolah, banyak siswa tampaknya kurang menarik dengan Matematika, sering bertanya Begitu banyak korelasi waktu menghabiskan belajar pelajaran ini. Namun, penelitian telah membuktikan pentingnya matematika di kehidupan sehari-hari. Matematika lebih penting daripada penerapan keterampilan numerasi dasar. 
Matematika juga merupakan hal utama untuk mengembangkan keterampilan berpikir logis dan keterampilan kognitif yang lebih tinggi pada anak-anak. Matematika juga memainkan peran penting dalam banyak bidang ilmiah lainnya, seperti fisika, teknik dan statistik (Muijs and Reynolds, 2008: 332-333)

Menurut Permendiknas No. 22/2006, wajib dilaksanakan: Standar Kemampuan Lulusan Satuan Pendidikan Dasar (SKL-SP) Salah satunya adalah menunjukkan kemampuan memecahkan masalah sederhana simple dalam kehidupan sehari-hari. Namun dengan adanya kenyataan saat ini, baik siswa SD, SMP maupun SMA masih terjadi permasalahan. Proses pembelajaran matematika membutuhkan perhatian dan pengolahan yang serius. Hal ini penting karena hasil penelitian masih menunjukkan bahwa proses pembelajaran matematika sekolah dasar masih berlangsung dan belum menunjukkan hasil yang memuaskan. Masih banyak teman sekelas yang sulit memahami pembelajaran matematika. Dalam memecahkan suatu masalah pada kehidupan sehari-hari siswa masih mengalami kesulitan dalam memahami, menalar dan memecahkan suatu masalah.

Banyak siswa yang masih mengalami kesulitan dalam mempelajari matematika. Karena sebagian besar siswa masih menganggap matematika itu sulit, dan takut. Anggapan ini membuat siswa merasa takut ketika mengikuti pembelajaran matematika sehingga mempengaruhi minat, motivasi dan Hasil belajar matematika. Ketakutan, ketegangan, dan pemikiran tentang matematika sangat sulit dapat mengakibatkan rendahnya prestasi siswa dalam matematika. Surya (2005) menyimpulkan bahwa matematika adalah mata pelajaran yang sulit untuk dipelajari sudah melekat pada sebagian besar siswa, jadi ketika menghadapi kursus. Siswa matematika menjadi malas berpikir. Bilangan bulat adalah materi dalam matematika diajarkan di sekolah dasar. Materi bilangan bulat diajarkan di sekolah dasar karena banyak sekali manfaatnya dalam kehidupan sehari-hari. Penguasaan materi digital putaran akan membantu siswa mempelajari materi selanjutnya. Teori yang perlu dikuasai siswa sekolah dasar adalah operasi hitung, dan solusi untuk masalah. Materi untuk menyelesaikan soal bilangan bulat biasanya diwujudkan dalam bentuk soal cerita, ini salah satunya banyak siswa yang merasa kesulitan.

Beberapa alasan diatas mendorong peneliti untuk menganalisis kesulitan yang dialami siswa kelas IV dalam mengerjakan soal bilangan bulat dengan penelitian yang berjudul "Analisis Kesulitan Dalam Pembelajaran Matematika Mengenai Materi Bilangan bulat di Kalangan SD Pada Masa Pandemi Covid-19”.

\section{METODE}

Penelitian dilakukan pada anak SD kelas IV SDN 01 Kartoharjo. Untuk waktu penelitian kami mengambil pada semester genap 2020/2021 pada bulan Juni 2021. Pada penelitian ini penulis mengambil sampel dengan cara purposive sampling. Purposive sampling adalah Teknik pengambilan sample dengan menentukan kriteria-kriteria tertentu. (Sugiyono, 2008). Untuk menganalisis kesulitan siswa maka terdapat 6 jawaban siswa yaitu 2 anak yang dapat menyelesaikan dengan baik dan 4 anak yang masih memperoleh nilai dibawah rata-rata. Dari ke 6 siswa tersebut dapat kita ambil dengan kriteria siswa yang memiliki penyelesaian dalam permasalahan.

Sesuai jenis penelitian yang dipilih yaitu penelitian kualitatif, maka yang menjadi instrumen atau alat penelitian utama adalah peneliti itu sendiri. Jadi, peneliti merupakan instrumen kunci dalam penelitian kualitatif. Setelah focus penelitian menjadi jelas maka kemungkinan akan dikembangkan menjadi penelitian sederhana yang diharapkan dapat melengkapi data dan membandingkan dengan data yang ditemukan melalui tes, wawancara dan dokumentasi. Untuk mengetahui kompetensi siswa dalam mempelajari materi operasi bilangan bulat maka peneliti membuatkkan soal yang terdiri dari 5 soal. Penelitian ini dirancang dengan serangkaian pertanyaan yang disusun dalam suatu daftar pertanyaan.

\section{HASIL DAN PEMBAHASAN}

Pada penelitian ini, digunakan metode tes untuk mendapatkan informasi tentang kesulitan belajar yang dialami siswa setelah mempelajari materi operasi bilangan bulat. Setelah menyelesaikan menganalisis jawaban siswa dalam ujian menulisnya, peneliti ingin 
memastikan informasi mendalam dari hasil analisis tersebut. Berdasarkan hasil pekerjaan siswa dalam ujian tertulis, dapat menyiapkan panduan wawancara yang dapat digunakan peneliti dalam melakukan wawancara kepada subjek penelitian yaitu siswa.

Berdasarkan hasil wawancara dengan responden dengan kriteria akademik, diperoleh informasi bahwa siswa tersebut sudah menguasai konsep bilangan bulat dalam menyelesaikan soal cerita, dapat membedakan penggunaan operasi bilangan bulat dalam soal cerita. Namun, berdasarkan hasil jawaban lembar tugas siswa, ditemukan bahwa pada umumnya siswa kesulitan mengoperasikan bilangan yang memuat tanda negatif; kesulitan menerjemahkan maksud soal ke dalam kalimat matematika, kesulitan memahami lambang sama dengan "="; kesulitan dalam melakukan operasi hitung pembagian, kesulitan memahami makna lambang tanda kurung "( )". Berikut ini dijelaskan secara lebih detail mengenai kesulitan matematika siswa sekolah dasar sebagaimana yang disebutkan diatas terutama dalam menyelesaikan dua jenis soal baik soal bentuk kalimat matematika langsung dan soal cerita pada materi operasi hitung bilangan bulat.

Kesulitan dalam mengartikan maksud soal kedalam kalimat matematika diawali dengan kesulitan siswa memahami maksud soal. Seringkali kesulitan memahami maksud soal ini menyebabkan siswa tidak dapat menyelesaikan soal. Kesulitan dalam memahami dan mengartikan soal ke dalam kalimat atau bentuk matematika yaitu penyelesaian soal cerita. Menghadapi soal cerita matematika, siswa harus lebih dahulu menganalisa informasi untuk dijadikan landasan dalam menentukan pilihan dan keputusan dalam mnyelesaikan suatu soal matematika. Kesulitan dalam menerjemahkan soal ke dalam bentuk matematika ini yaitu berkaitan dengan memecahkan persoalan yang berbentuk cerita berarti menerapkan pengetahuan yang dimiliki secara teoritis untuk menyelesaikan persoalan nyata dalam kehidupan sehari-hari. Hal tersebut sesuai dengan beberapa pendapat bahwa kesulitan dalam mengerjakan soal cerita disebabkan karena siswa kurang cermat dalam membaca dan memahami kalimat per kalimat serta mengenai apa yang diketahui dalam soal apa yang dinyatakan, serta bagaimana cara menyelesaikan soal secara tepat (Muncarno, 2008; Paridjo, 2012: 7; Kartikasari, 2017). Kesulitan dalam memahami maksud soal dan menerjemahkannya ke dalam kalimat matematika dialami oleh semua subjek. Berikut ini adalah beberapa gambarannya :

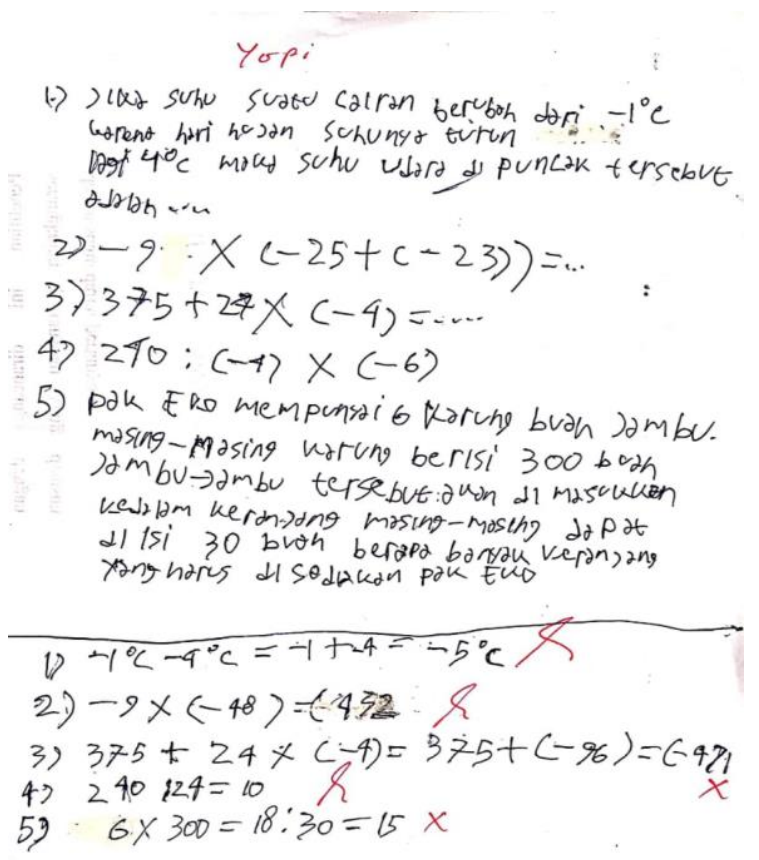

Gambar 1. Siswa masih salah dalam menghasilkan Jawaban 
Berdasarkan hasil wawancara dengan peserta didik, dari gambar 1, terlihat S1 (siswa pertama) salah dalam menghasilkan jawaban. Karena pada jawaban no. 3 responden menulis 375 $+24 \times(-4)=375+(-96)=(-471)$. Jadi seharusnya hasil yang benar adalah 279 bukan $(-471)$ sehingga pada penyelesaian masih ada kesalahan dan juga kurangnya tanda kurung"( )". Selanjutnya, pada soal no.5 S1 masih kesulitan dalam soal cerita. Untuk soal cerita S1 sudah bisa memahami apa yang ditanyakan tetapi, S1 masih salah menghasilkan jawaban.

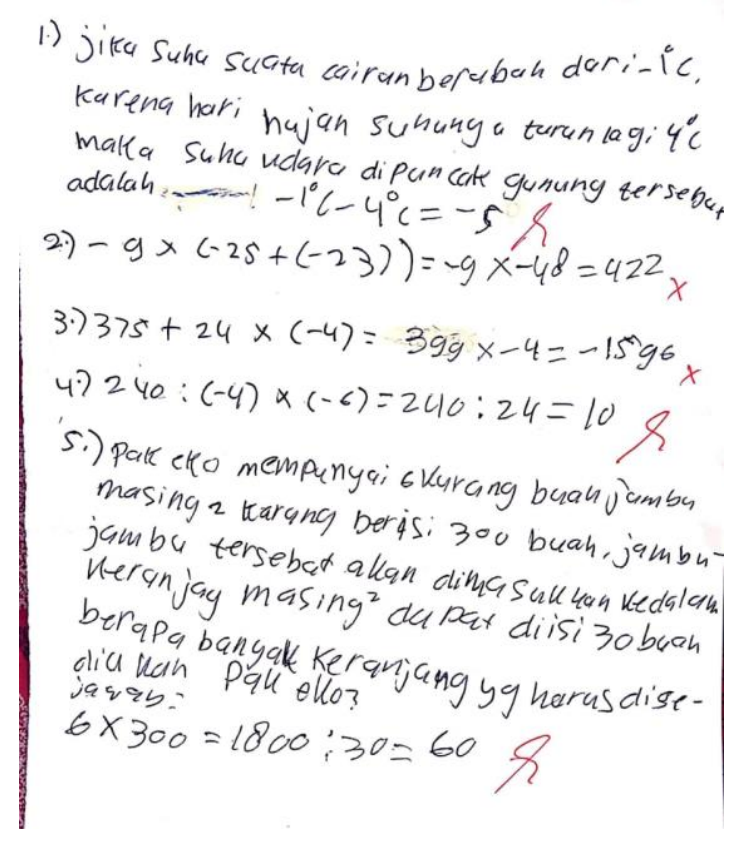

Gambar 2. Siswa Belum memahami Soal secara keseluruhan

Berdasarkan jawaban pada lembar tugas, S2 (siswa kedua) belum bisa memahami soal secara keseluruhan dan masih kesulitan dalam memahami makna lambang tanda kurung "( )". Pada soal no.2 S2 masih belum paham dalam perkurungan sifat operasi hitung dan juga dalam perhitungan masih ada kekeliruan. Selanjutnya untuk soal no.3 S2 tidak memahami soal secara utuh. S2 kurang cermat dalam memahami kalimat mengenai apa yang diketahui dalam soal, apa yang ditanyakan dan bagaimana cara menyelesaikan soal secara tepat.

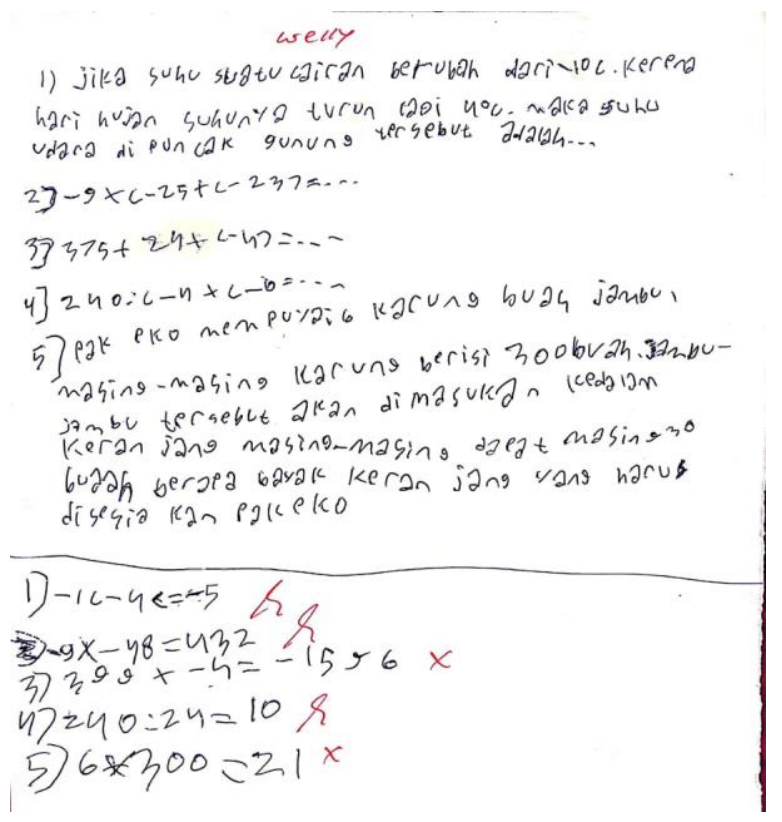

Gambar 3. Siswa Masih Belum Paham Guna Dari Tanda Yang Ada Pada Soal 
Berdasarkan gambar diatas, S3 (siswa ketiga) hampir sama dengan S2 dalam pengerjaan soal no. 3. Siswa masih belum paham apa guna dari tanda yang ada pada soal. Dan untuk soal pada no. 5 siswa masih belum dapat memahami soal cerita yang disajikan pada gambar diatas, menurut S3 ia belum memahami soal dalam bentuk angka apalagi jika soal tersebut diubah kedalam betuk soal cerita.

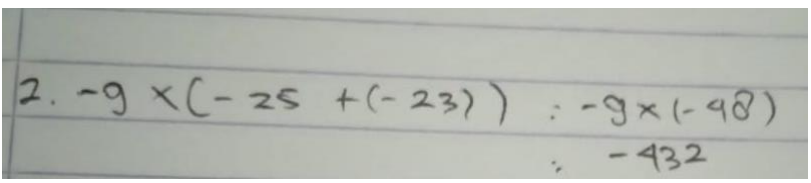

Gambar 4. Siswa Belum Memahami Tentang Perkalian Minus

Berdasarkan hasil jawaban dari S4 (siswa keempat), siswa tersebut belum bisa memahami dan tidak teliti tentang perkalian minus (-) dan plus (+), jika minus dikalikan plus maka hasilnya akan menjadi minus begitupun sebaliknya, sedangkan perkalian antara minus bertemu dengan minus maka hasilnya akan menjadi plus. Pada soal no. 2 siswa masih kesulitan membedakan hasil yang ia cari.

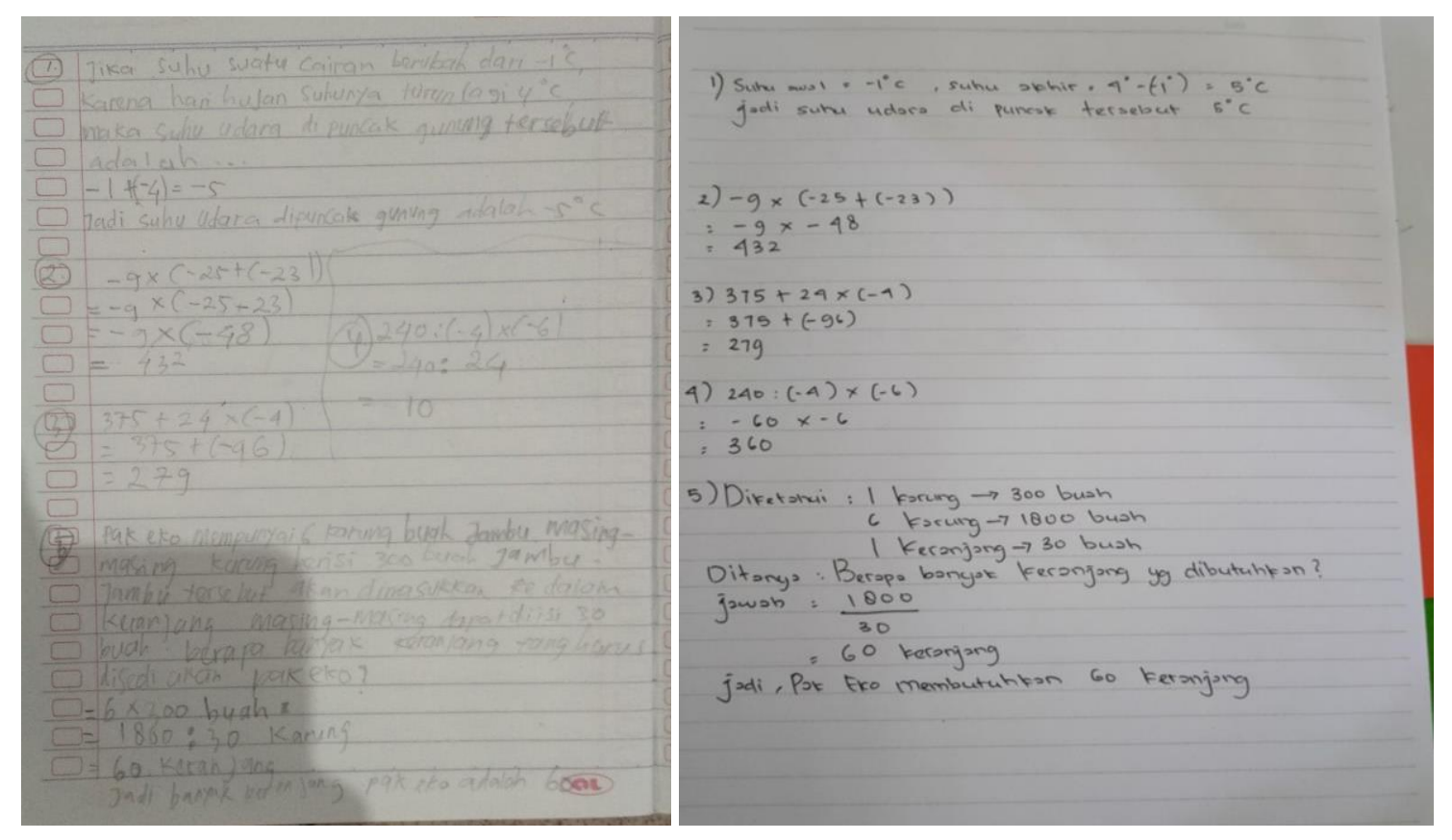

Gambar 5. Siswa Sudah memahami materi Sifat Operasi Hitung

Berdasarkan gambar diatas S5 (siswa kelima) dan S6 (siswa keenam) sudah memahami materi sifat operasi hitung bilangan bulat dan juga dapat menelaah soal cerita yang ada pada pertanyaan.

Berdasarkan hasil penelitian terhadap jawaban dari tes tertulis dan hasil wawancara dengan siswa yang mengalami kesulitan dalam menyelesaikan soal operasi hitung bilangan bulat diatas. Maka dapat kami simpulkan sebagai berikut :

1. Pemahaman siswa dalam penjumlahan dan pengurangan sifat operasi bilangan bulat masih kurang. Hal ini dikarenakan siswa mengalami kesulitan mengoperasikan bilangan yang memuat tanda negatif; kesulitan menerjemahkan maksud soal ke dalam kalimat matematika, kesulitan memahami lambang sama dengan "="; kesulitan dalam melakukan operasi hitung pembagian, kesulitan memahami makna lambang tanda kurung "( )". Sehingga siswa masih belum dapat menguasai operasi bilangan bulat tersebut.

2. Pemahaman siswa terhadap sistem operasi bilangan bulat masih kurang. Soal-soal yang mengenai operasi hitung penjumlahan, pengurangan, perkalian dan pembagian antara 
bilangan positif dan negatif kebanyakan siswa mengalami kesulitan dalam menyelesaikannya.

3. Kemampuan siswa dalam menyelesaikan soal cerita dan penalaran maupun pemecahan soal masih kurang. Soal-soal dalam matematika terbagi menjadi 3 aspek yaitu soal tentang pemahaman konsep, penalaran dan komunikasi maupun soal pemecahan masalah (Depdiknas, 2006:346). Untuk soal yang membutuhkan penalaran banyak siswa yang masih mengalami kesulitan dalam menyelesaikannya. Kesulitan ini dikarenakan siswa masih kurang latihan dengan soal-soal yang bervariasi tingkat kesulitannya. Selain itu, kesulitan juga disebabkan karena siswa yang mudah menyerah dan kurang gigih dalam menyelesaikan permasalahan tersebut.

4. Kurangnya pengulangan materi yang diajarkan oleh guru kepada siswa. Hal ini dikarenakan keterbatasan waktu mengajar guru dengan kemampuan yang harus dicapai oleh siswa. Sehingga dalam menyelesaikan soal beberapa siswa lupa cara dalam menyelesaikannya walaupun waktu bertatap muka sudah pernah diajarkan. Oleh karena itu, dapat disimpulkan bahwa siswa mengalami kesulitan belajar Masalah teratasi karena guru tidak lagi memberikan penguatan konseptual. Guru menilai bahwa konsep akan mudah dipahami melalui praktik. bahkan jika diperkuat gagasan siswa pada awal pembelajaran sebelum melakukan pekerjaan sangat penting diajarkan.

\section{SIMPULAN}

Berdasarkan penelitian, maka dapat disimpulkan bahwa rata rata siswa SD kelas IV SDN 01 Kartoharjo masih kurang dalam memahami operasi bilangan bulat dan kemampuan siswa dalam menyelesaikan soal berbentuk cerita dan penalaran masih kurang dengan bukti bahwa pada saat 6 siswa kelas IV SDN 01 Kartoharjo diberikan 5 soal mengenai operasi bilangan bulat dan soal berbentuk cerita, dari total 6 siswa tersebut yang menjawab semua soal cerita dengan benar terdapat 3 siswa dan yang menjawab semua soal oprasi bilangan bulat dengan benar terdapat 2 siswa dan terdapat 3 siswa yang menjawab sebagian soal berbentuk cerita dan soal oprasi bilangan bulat dengan jawaban kurang tepat atau salah dan dari 6 siswa IV SDN 01 Kartoharjo yang menjawab semua soal dengan benar terdapat 2 siswa, yang menjawab 4 soal dengan benar dan kesalahan menjawabnya terletak pada soal oprasi bilangan bulat terdapat 1 siswa dan 3 siswa sisanya menjawab 3 soal dengan benar dan kesalah menjawabnya terdapat di soal berbentuk cerita dan soal oprasi bilangan bulat.

\section{DAFTAR PUSTAKA}

Aunurrahman. (2010). Belajar dan Pembelajaran. Bandung: Alfabeta.

Burhanuddin, N. (2018). filsafat ilmu. Jakarta Timur: Prenadamedia Group.

Maizora, S. (2020). konsepsi siswa kelas 3 sekolah dasar tentang bilangan bulat. phytagoras, 48 .

Muncarno. (2008). Penerapan Model Penyelesaian Soal Cerita dengan Langkah-langkah Pemecahan Masalah untuk Meningkatkan Prestasi Belajar Matematika . Jurnal Nuansa Pendidikan, Vol.6 No. 1.

Pahlevi, B. (2020, December 31). kesulitan belajar daring dimasa pandemi covid-19. Retrieved fromkompasiana:https://www.kompasiana.com/berthanandityajeni/5fecd14b8ede4860875a3 292/kesulitan-belajar-daring-di-masa-pandemi-covid-19

Paridjo. (2012). Sebuah Solusi Mengatasi Kesulitan Matematika. semarang: Universitas Terbuka.

Partowisastro, K. (1986). Diagnosa dan Pemecahan Kesulitan Belajar. Jakarta: Erlangga.

Utomo, K. D. (2021). pemecahan masalah kesulitan belajar siswa pada masa pandemi covid-19 kelas IV SD. Mimbar PGSD Undiksha, 1-6 